\title{
The Amazon basin as a moisture source for an Atlantic Walker-type Circulation
}

\author{
R. Hierro ${ }^{a, *}$, P. Llamedo ${ }^{a}$, A. de la Torre ${ }^{a}$, P. Alexander ${ }^{b}$

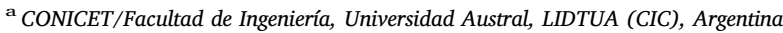 \\ ${ }^{\mathrm{b}}$ CONICET/Instituto de Física de Buenos Aires (IFIBA), Argentina
}

\section{A B S T R A C T}

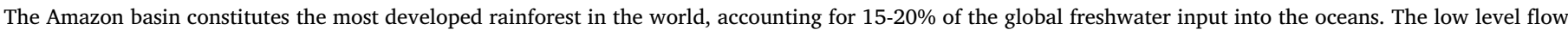

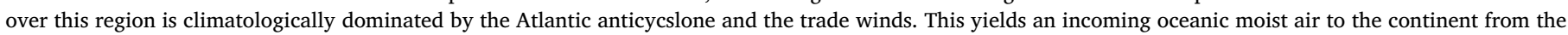

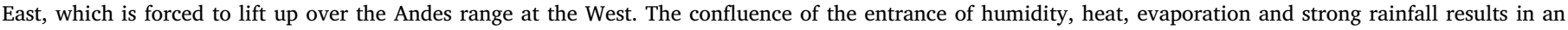

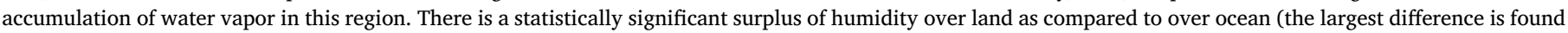

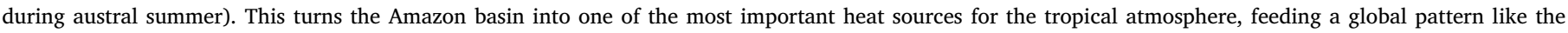

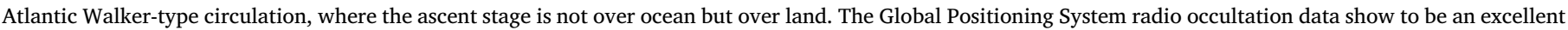
tool to observe the accumulated water vapor above the Amazon basin.

\section{Introduction}

The atmospheric transport of heat and momentum from the Equator to the poles is mainly explained by conceptual models of meridional tropospheric circulations known as Polar, Ferrel and Hadley cells. Longitudinally, the transport is given by zonal circulations forced by thermal gradients over the surface of the seas. The dominant circulation, called the Walker circulation (after G. T. Walker) by Bjerknes (1969), is mainly located over the equatorial Pacific Ocean. According to Barry and Chorley (2009), during the phases corresponding to no ENSO (El Niño Southern Oscillation) conditions, high sea surface temperatures over the western Pacific favor strong convection and its associated upward motion. Over the Eastern Pacific, the air carried by the westerly upper level flow descends over the cold water. Finally, the Walker cell is closed with the easterly trade winds over the surface (Fig. 1a, red full line). The narrower width of the Atlantic Ocean (WestEast direction), in turn, hinders the formation of a Walker-type circulation (i.e. Wang, 2005). However, if we consider the South American continent as part of the circulation, we find a similar pattern, composed of an upward path over the Amazon basin and a downward trajectory over the Atlantic ocean (Fig. 1a, blue full line). The cause of this effect lies in the Amazon region, which is one of the biggest tropical heating centers of the Earth, with the most developed rainforest in the world. The basin covers an area close to $40 \%$ of South America (about 650 million hectares) roughly delimited in longitude and latitude by 75 $45 \mathrm{~W}$ and $0-20 \mathrm{~S}$. This region accounts for $15-20 \%$ of the global freshwater input into the oceans and its large annual regional precipitation is one of the important heat sources for the tropical atmosphere (Nobre et al., 2004). This feature of the Amazon basin may be explained by its geographical characteristics (latitude range, topography and location between two oceans), as well as by its regional low level atmospheric circulation (Fig. 1b). The latter factor plays a major role in transporting water vapor, since nearly half of it resides below an altitude of about $1.5 \mathrm{~km}$ and less than $5 \%$ is above $5 \mathrm{~km}$ (Seidel, 2002). In this case, the Atlantic anticyclone, the trade winds and monsoon flux from the North provide an incoming low level moist flow which, when located over the continent, is mostly channeled to the south at the eastern side of the Andes range (e.g. do Nascimento et al., 2016 and references therein). This acts as a major barrier for the surface trade winds (Fig. 1b, white curve over the continent), giving place to upward motion and strong precipitation over its slopes. This rainfall with the available heat then yields a strong evaporation, which, together with the arriving humidity contribute to the different stages of the water cycle in this region.

South America is characterized by its large oceanic area and the presence of the Andes range from north to south, which make difficult to set up a good radiosonde network over the region. The development of continuous satellite measurements with a regional coverage, allowed to observe thermal and dynamic processes over South America that were possible only with model data in the past. This is the case of the Global Positioning System (GPS) radio occultation (RO). It is a unique satellite method regarding the retrieval of global and continuous

\footnotetext{
* Corresponding author at: CONICET/Facultad de Ingeniería, Universidad Austral, LIDTUA (CIC), 16 Acosta 1901, 1629 Pilar, Buenos Aires, Argentina

E-mail address: Rhierro@austral.edu.ar (R. Hierro).
} 
a)

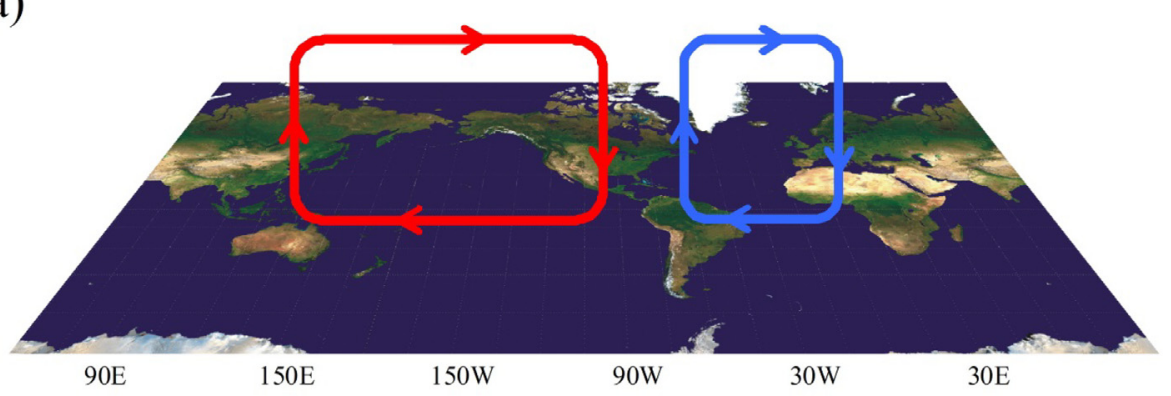

b)

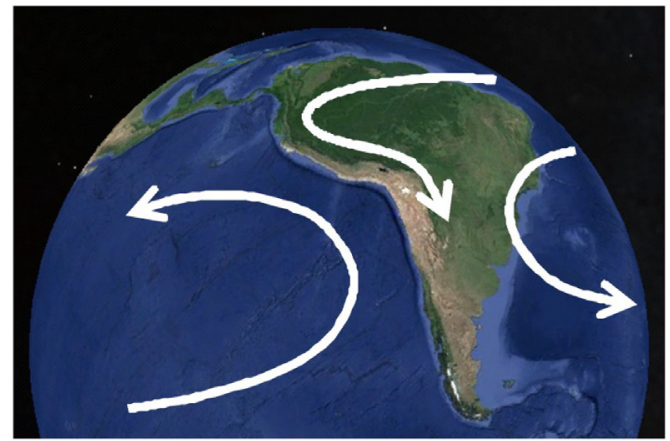

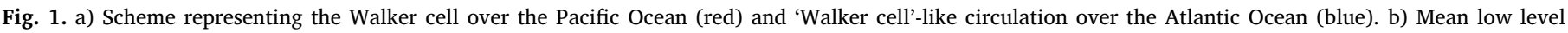

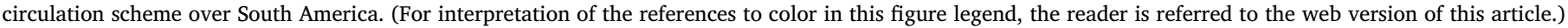

atmospheric data and it is not affected by meteorological conditions. In April 2006, the Constellation Observing System for Meteorology, Ionosphere and Climate (COSMIC) launched six GPS RO satellites, which significantly increased the number of daily soundings at that time. For several years it provided about 2000 daily profiles of water vapor, temperature, refractivity and pressure from the lower troposphere up to the middle stratosphere. The present study analyzed the post-processed data version 2013.3520 provided by the COSMIC Data Analysis and Archive Center. A good concordance between radiosonde data and the COSMIC mission water vapor distribution $\left(50^{\circ} \mathrm{S}-50^{\circ} \mathrm{N}\right)$ was found by Kishore et al. (2011). The water vapor pressure measured by GPS RO can be easily converted into specific humidity $q$ (e.g. Hierro et al., 2012). This is a representative tropospheric water vapor variable which relates the mass of water vapor with the total mass of an air parcel.

Space- and ground-based GPS technqiues have in general shown to be a useful tool for studying several meteorological features of the lower atmosphere (e.g. Kuleshov et al., 2016; Bonafoni and Biondi, 2016). In the case of humidity measurements, the integrated water vapor from both sources has been validated against other measurement methods and reanalysis data (e.g. Huang et al 2013, Calori et al., 2016). In particular, the space-based GPS RO technique has demonstrated to be a powerful tool for studying the global distribution of water vapor over land and sea with a moderate/high spatial and temporal resolution. The tropospheric mean patterns of humidity at different levels have been reproduced by Hierro et al. (2012). They showed that this technique is able to detect the behavior of this variable at a regional scale in South America. Oscillation modes of the integrated specific humidity derived from GPS RO over the Amazon basin were analyzed by Hierro et al. (2013). Llamedo et al. (2016), in turn, have shown the usefulness of this technique to study the water vapor over land and sea with a moderate/ high spatial and temporal resolution, as well as its anomalies.

GPS RO retrievals usually provide temperature, refractivity and water vapor against height or pressure. The uncertainty of the former two variables has been assessed e.g. by Alexander et al. (2014) but will not be further considered as they are both not used in this study. The reliability of GPS RO water vapor or specific humidity has been evaluated in several works. Chou et al. (2009) compared COSMIC and AIRS (Atmospheric Infrared Sounder) tropospheric $q$ globally and also specifically in the tropical Pacific and found discrepancies within $15 \%$, whereas global validations against NCEP (National Centers for Environmental Prediction) reanalysis showed differences around $30 \%$ in oceanic areas above $300 \mathrm{hPa}$, but it should be kept in mind that those heights typically make a small contribution to the total vertical column amount of water vapor. According to Ho et al. (2010) the COSMIC water vapor profiles exhibit discrepancies within $0.2 \mathrm{~g} / \mathrm{kg}$ in the lowest $2 \mathrm{~km}$ when compared with ECMWF (European Centre for MediumRange Weather Forecasts) global analyses and $0.05 \mathrm{~g} / \mathrm{kg}$ above. In addition, Teng et al. (2013) have shown a very good agreement of $q$ from COSMIC and NCEP reanalysis in the lowest $5 \mathrm{~km}$ over the tropical Pacific. Vergados et al. (2018) have shown that RO COSMIC specific humidity profiles have a $10-20 \%$ precision within the layer $400-700 \mathrm{hPa}$. Teng et al. (2013) estimated that on average the biases of precipitable water $(P W)$, which is essentially the vertical integral of specific humidity in the troposphere, remain within $2 \mathrm{~mm}$. Also, Burgos Fonseca et al. (2018) validated GPS RO $P W$ against values derived from groundbased GPS retrievals (see e.g. Calori et al. 2016) and found a global mean difference around $1 \mathrm{~mm}$, which represented on average a discrepancy around 5\%. Finally, notice that besides uncertainty issues, GPS RO data have the significant advantage over reanalysis that they are experimental values. On the contrary, $P W$ and $q$ belong to the reanalysis output variables category B (Kalnay et al., 1996), which means that although observational information affects their value, the numerical model has a strong influence on them. $P W$ from reanalyses neither are usually given an associated uncertainty nor should they be considered standard benchmark data. In addition, Burgos Fonseca et al. (2018) have shown that $P W$ over land from models may be significantly biased if their representation of the terrain height is not accurate enough. Among the diversity of observational instruments providing $P W$ and $q$, satellite platforms are the only ones capable of providing 


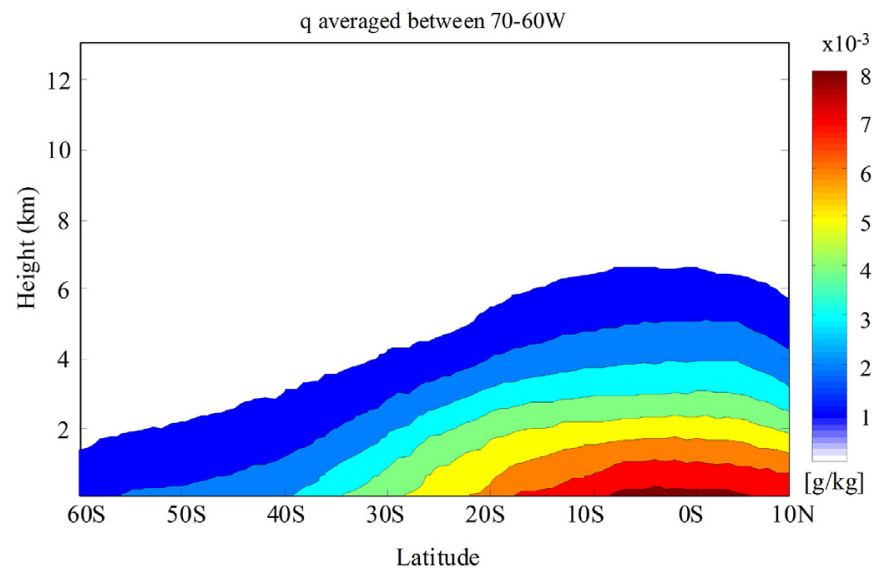

Fig. 2. Latitudinal distribution of mean specific humidity averaged between 7060W derived from GPS RO (COSMIC) data, during the period 2006-2014.

permanent and global soundings over land and over ocean.

\section{Water vapor and circulation}

Fig. 2 shows the latitudinal distribution of $q$ derived from GPS RO (COSMIC) data, averaged during the period 2006-2014 between 70 $60 \mathrm{~W}$, which covers the central part of South America. A maximum of humidity is observed close to the surface around the equator, slightly towards the Southern Hemisphere. Fig. 3 shows the longitudinal distribution of $q$, seasonally averaged between latitudes $0-20$ S. One interesting feature observed is the already mentioned stopping effect of the Andes Range on the incoming flow from the East. This is evident from the strong gradient (enhanced during the July-November period) located at the lee side of the mountains (80-75W). Regardless of the seasonal characteristics, all $q$ slices show a marked land-ocean difference at any given level. The most significant case corresponds to DJF, which exhibits a decreasing amount of $q$ around $50 \%$ in 15 degrees (about $1500 \mathrm{~km}$ ) close to the Atlantic coast surface level in the landocean direction. Although during Southern Hemisphere winter time this difference is lower, the change rate is still important, amounting to almost half of the summer one.

As a way of quantifying these longitudinal changes, the Pettitt inhomogeneity test (Pettitt, 1979) has been applied to $q$ at the eastern side of the Andes Range. With a 99\% confidence level, the Pettitt test shows a significant change in the signal at $41 \mathrm{~W}, 36 \mathrm{~W}, 37 \mathrm{~W}$ and $39 \mathrm{~W}$ during the months of summer (DJF), autumn (MAM), winter (JJA) and spring (SON) respectively. These longitudes are represented by black vertical solid lines in Fig. 3. The grey column indicates the representative land-ocean limit derived from NCEP data. A good match between the column and the vertical lines indicates that, from the Pettitt test, $q$ becomes longitudinally larger exactly over the coast.

Fig. 4a uses $u$ and $w$ from NCEP (National Center for Environmental Prediction) reanalysis data, which are respectively defined as the zonal velocity component and as $d p / d t$ (change of pressure over time for an air parcel), whereby $\omega$ is then converted into vertical velocity $w$ by a standard procedure. Both velocity components are shown versus longitude averaged during the years 2006-2014 between 20S-Equator. The Walker-type cell structure may be easily identified. Ascent movement is clearly observed over the Amazon basin roughly above 70-50W. Once formed, the system is in a certain way self-maintained. Strong convection is forced by low level convergence of mass and water vapor, then yielding condensation and releasing heat within the middle and upper troposphere. At mid-levels the divergence/convergence reach a minimum. The evaporation over the Amazon Basin yields an increase of temperature in the troposphere through the later release of latent heat. The released heating develops a divergent flow above, which in turn by

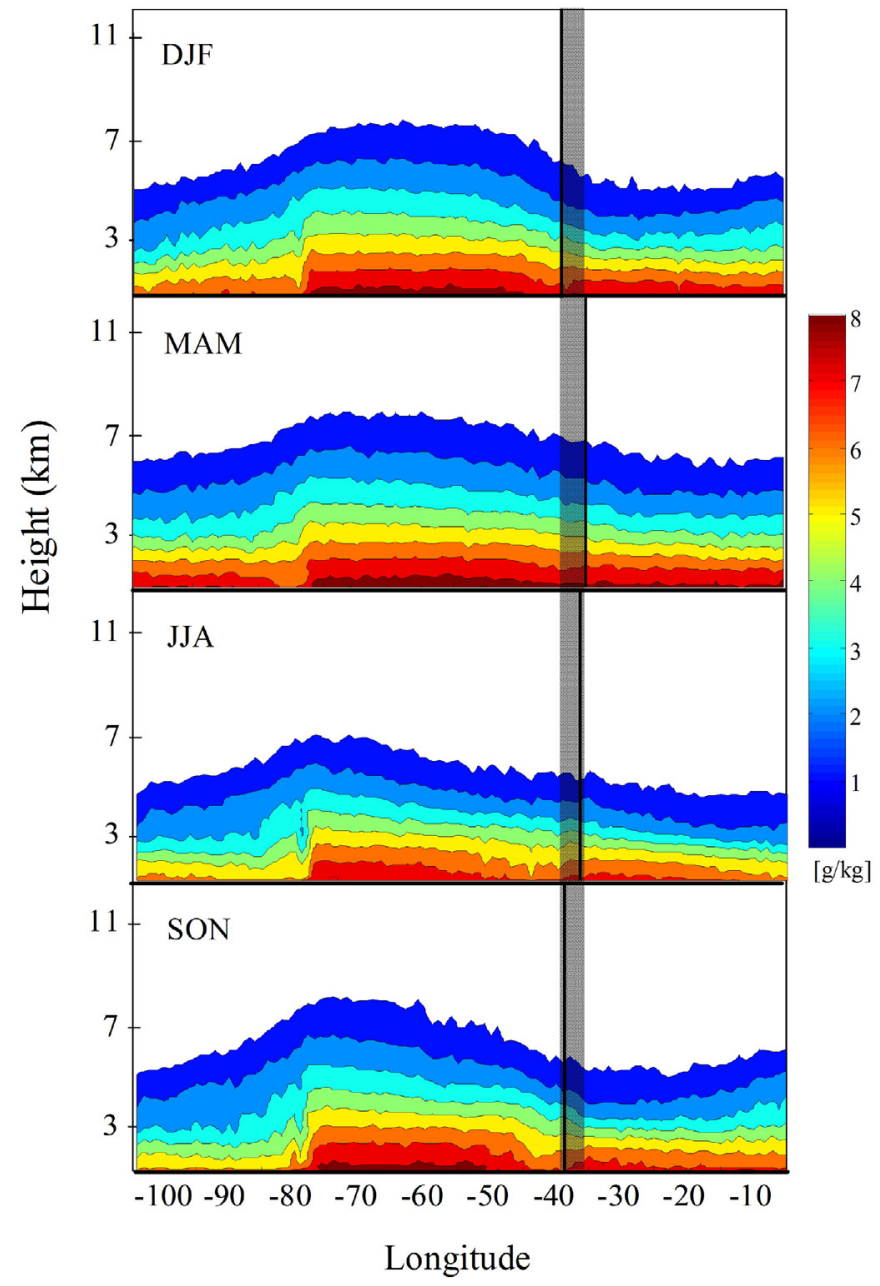

Fig. 3. Vertical-longitudinal slide of seasonal mean specific humidity averaged between 20S-Equator derived from GPS RO (COSMIC) data, during the period 2006-2014. Grey column indicates the land-ocean limit (Atlantic). Black lines indicate a change in the series homogeneity from the Pettitt test.

mass conservation keeps the convergent flow below alive. Under the described conditions, the necessary energy source to feed global circulation patterns like the Atlantic Walker cell may be supplied by the strong rainfall, which can be, in some locations, sustained during several days with precipitation rates of about $30 \mathrm{~mm} / \mathrm{h}$ (Oliveira et al., 2016). As a result, an accumulation of humidity occurs in this region. Large temperatures in addition to the high water vapor content, turns the Amazon region into one of the most important heat sources for the tropical atmosphere. Fig. 4b shows the geographical area corresponding to the Atlantic Walker-type cell in the Southern Hemisphere. It can be seen that the descent stage of the cell shown in Fig. 4a occurs over the ocean in front of the African coast.

In order to look for evidence that the accumulation of moisture in the Amazon region favors the presence of the Atlantic Walker cell, we study the relation between both aspects. $P W$ over the surface rectangle $0-20 \mathrm{~S}$ and $70-50 \mathrm{~W}$ becomes here calculated as

$P W=\frac{1}{g} \int_{p s}^{p_{T}} q d p$

where $p s$ and $p t$ refer to the pressure of the surface and the top of the considered atmospheric column $(200 \mathrm{hPa})$. We will interpret that $P W$ is a proxy for the amount of moisture over the Amazon region. We define the average along latitudes $0-20 S$ of the circulation $(C)$ as 
a)

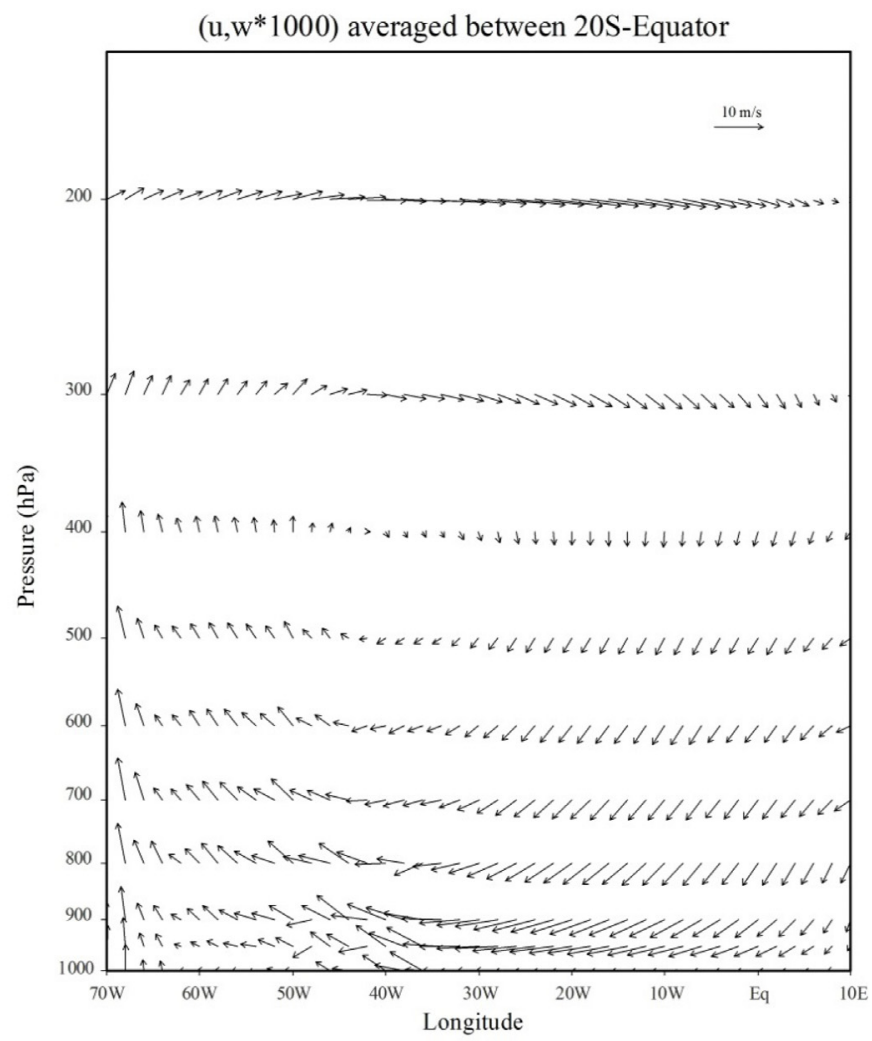

b)

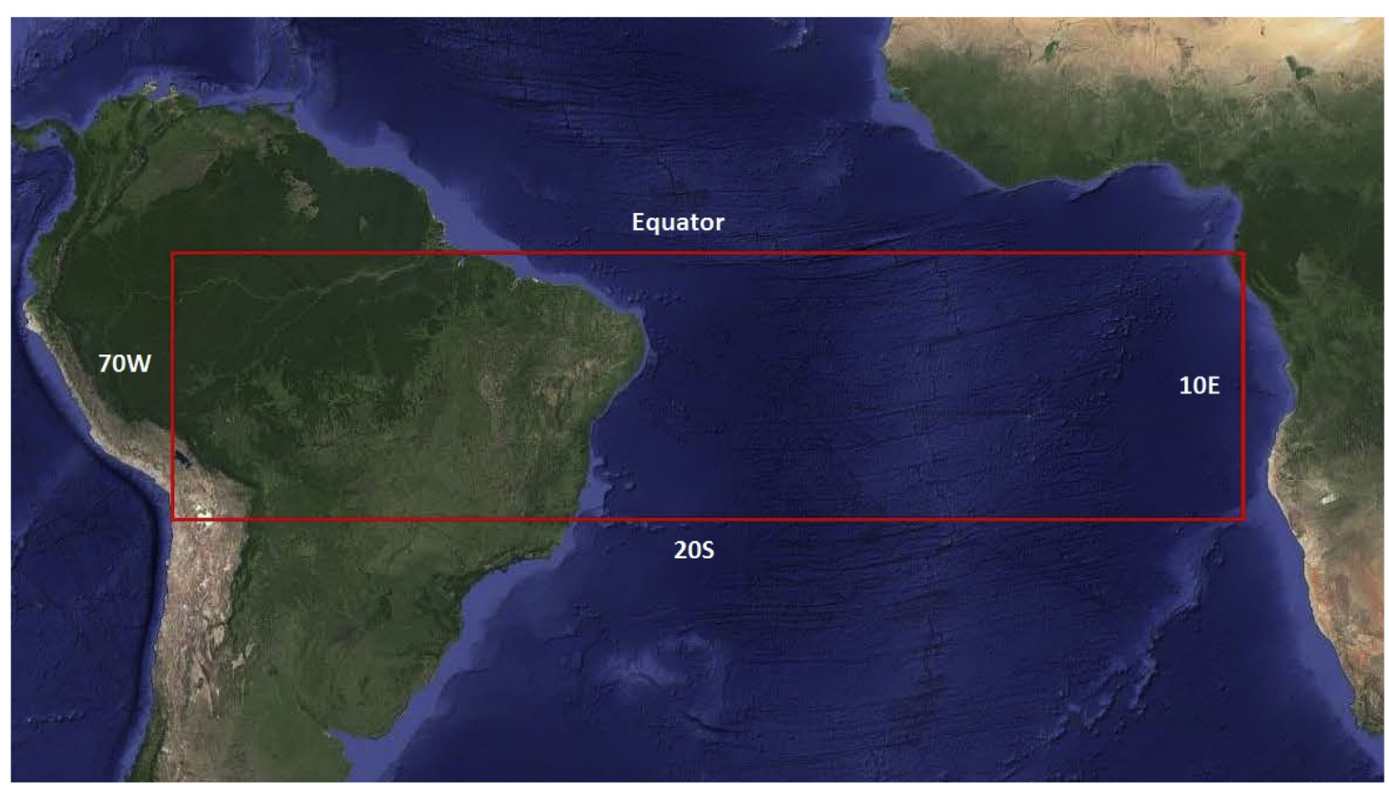

Fig. 4. (a) Vertical (log pressure) - longitudinal slide of zonal (u) and vertical (w) velocity components from NCEP data, averaged during 2006-2014 between 20SEquator. b) Geographical area covered by the cell.

$C=\frac{1}{L} \oint \underline{v} \cdot \underline{d} \underline{l}$

where the closed integral of velocity $\underline{v}$ (components $u, w$ ) along the path elements $\underline{d l}$ is calculated in the zonal rectangle defined by the surface level (E-W), 70W (upwards), $200 \mathrm{hPa}$ (W-E) and 10E (downwards) and $L$ is the total length of the integral perimeter. $C$ will be an indicator of the strength of the cell. Weekly values of $P W$ and $C$ are used, as we expect a priori any links between both to be visible on that scale up to a few months. In Fig. 5a we show both quantities between years 2007 and
2014 after removal of the long term mean and the filtering of fluctuations larger than one year. The dominant mode in both cases is clearly around 52 weeks (one year), which can be also seen in the continuous wavelet transform (CWT) analysis of both signals in Fig. $5 \mathrm{~b}$ and c. $C$ also exhibits a semi-annual behavior (26 weeks). In Fig. 5a a clear strong relation between both curves may be seen, where in general $P W$ variations precede changes in the intensity of the circulation. Isolation of the one year cycle in both quantities through a Fast Fourier Transform procedure leads to a phase difference of 2 weeks (average over the 
a)

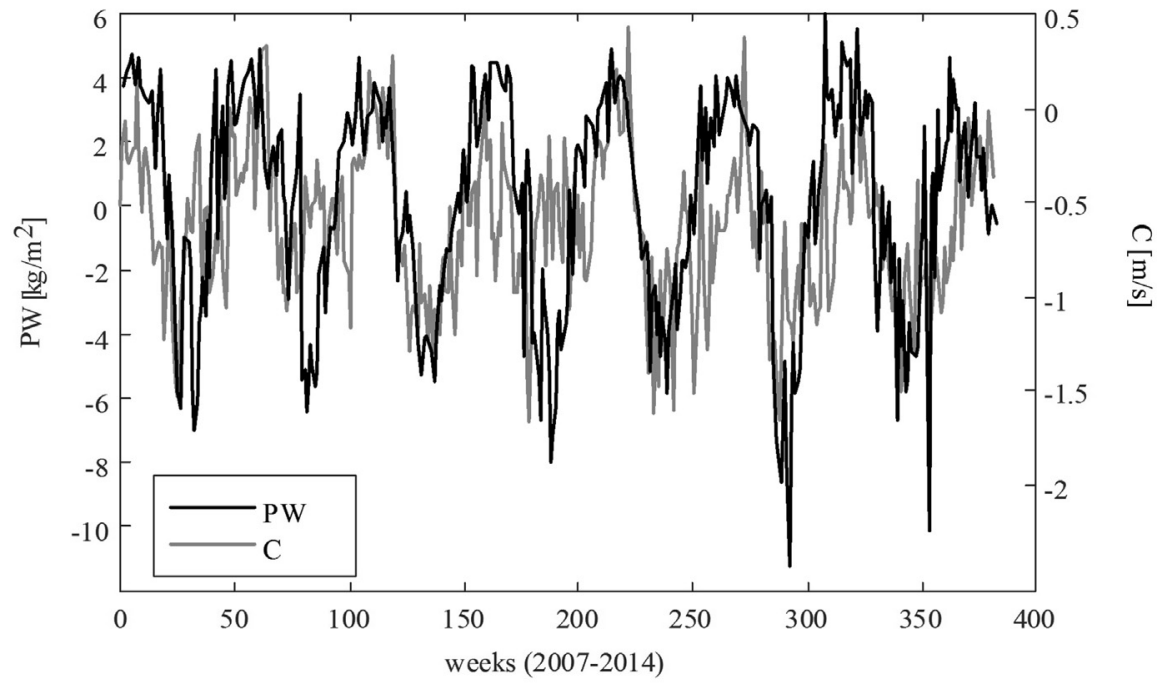

b)

CWT - PW

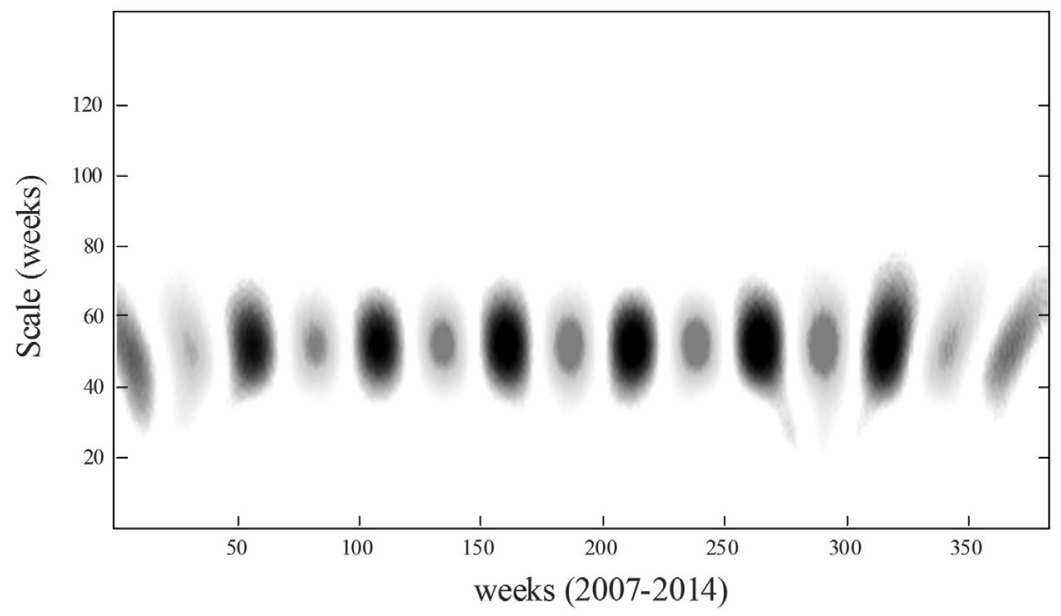

c)

CWT - C

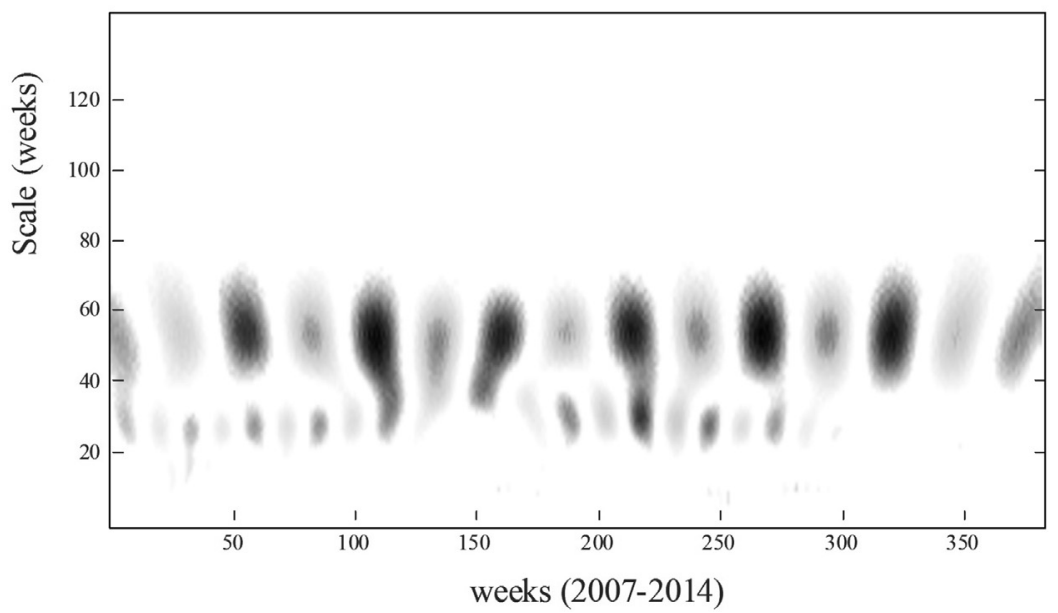

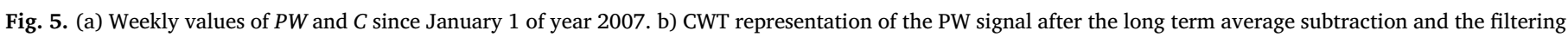
of oscillation periods above 1 year. c) The same as b) for quantity $C$. 
a)

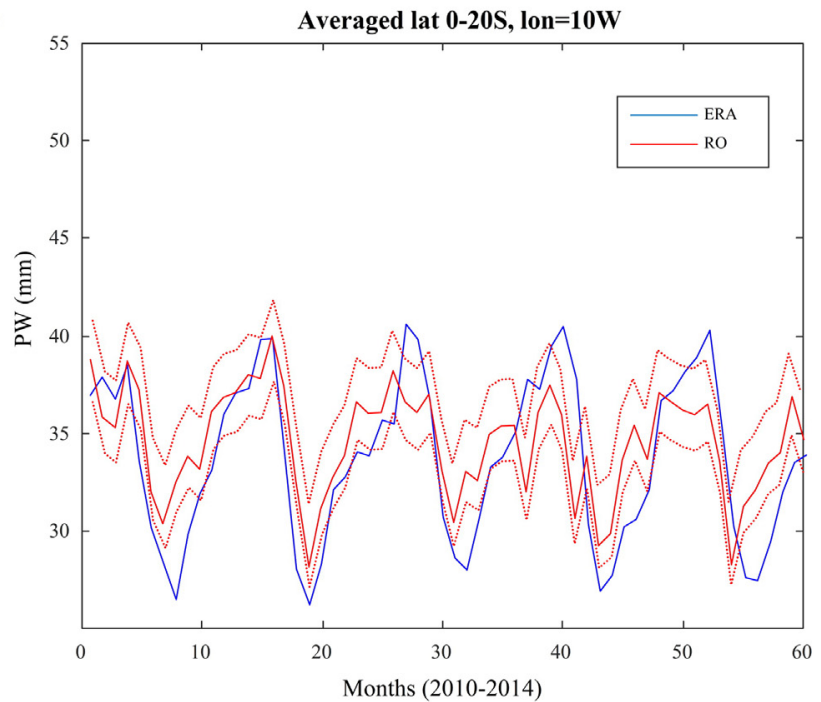

b)

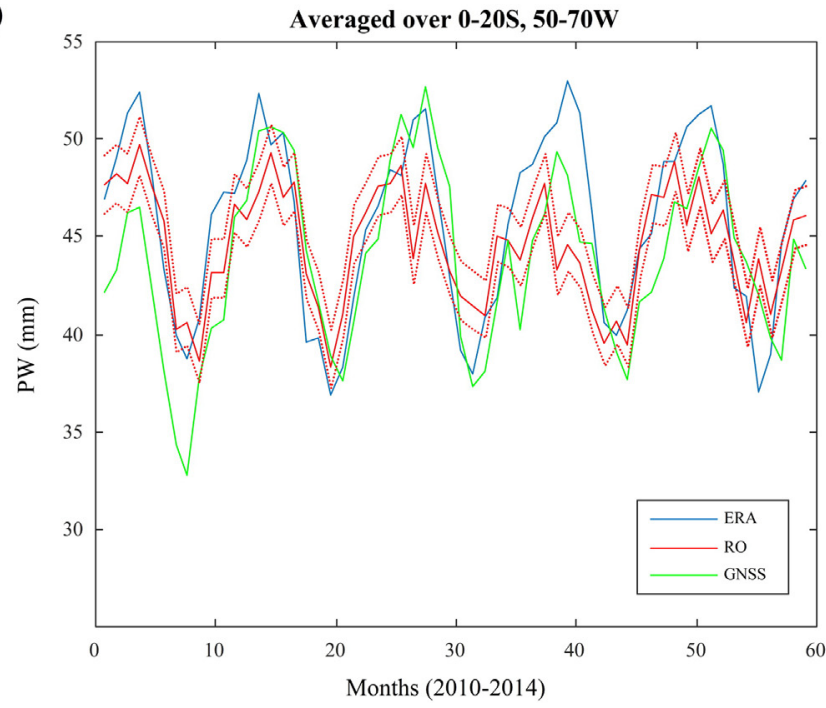

Fig. 6. PW provided by different sources against time at the descending and ascending legs of the Atlantic Walker-type cell: a) close to the African coast, b) Amazon basin. RO (continuous line) is enclosed by a $2 \mathrm{~mm}$ uncertainty (dotted line).

almost 8 years analysed). This would imply that the amount of moisture above the Amazon region may be considered a roughly 2 week precursor of the Atlantic Walker-type circulation strength and therefore one of its potential feeders.

We now use $P W$ in order to quantify the relevance of GPS RO water vapor errors and we will consider the Teng et al. (2013) $2 \mathrm{~mm}$ uncertainty estimation mentioned above to assess the impact of these biases. As another source of $P W$ observations in the Amazon basin we here also consider ground-based GPS. Five stations of the International GNSS Service network may be located in this region (name, longitude, latitude): POVE00BRA, $296.1^{\circ},-8.7^{\circ}$; BRAZ00BRA, 312.1 ${ }^{\circ}$, $-15.9^{\circ}$; SALU00BRA, $315.8^{\circ},-2.6^{\circ}$; BRFT00BRA, $321.6^{\circ},-3.9^{\circ}$; SAVO00BRA, $321.6^{\circ},-12.9^{\circ}$. In Fig. 6 we show $P W$ obtained from measurements by RO and ground-based GPS and from ERA Interim model data from the ECMWF. According to the RO uncertainty there is possible agreement with ground-based GPS and reanalysis data only at some specific periods. As the Eastern leg of the Atlantic Walker-type cell stays above the ocean, only RO measurements are available in Fig. 6a. If we want to use measurements to compare $P W$ behavior and values on both legs, then only RO observations remain available. The time evolution of the cycle on both sides is quite similar but the values are significantly different.
The annual cycle by RO observations on both legs exhibits in general smaller oscillation amplitudes than by ground-based GPS and ERA Interim data.

\section{Conclusion}

The Walker cell is an ocean-based system of air circulation which is the result of a difference in surface pressure and temperature over the western and eastern equatorial Pacific Ocean. Nowadays the term also usually refers to other similar but smaller and weaker cells in the tropics over the Atlantic and the Indian Ocean. We here show that the quality of GPS RO water vapor data is good enough to demonstrate that the moisture for the Atlantic Walker-type cell stems from the land humidity in South America and not from the sea, as opposed to the mechanism that is present over the Pacific Ocean.

\section{Acknowledgements}

The study has been supported by grants CONICET PIP 11220120100034 and ANPCYT PICT 2013-1097. We acknowledge NCEP and ERA Interim atmospheric model data provided by www. mmm.ucar.edu. GPS RO data downloaded from cdaac-www.cosmic. ucar.edu/cdaac/products.html and ground-based GPS data from rda.ucar.edu/datasets/ds721.1.

\section{References}

Alexander, P., de la Torre, A., Llamedo, P., Hierro, R., 2014. Precision estimation in temperature and refractivity profiles retrieved by GPS radio occultations. J. Geophys. Res. Atmos. 119, 8624-8638. https://doi.org/10.1002/2013JD021016.

Barry, R.G., Chorley, R.J., 2009. Atmosphere, Weather and Climate. Routledge, New York.

Bjerknes, J., 1969. Atmospheric teleconnections from the equatorial Pacific. Mon. Weather Rev. 97, 163-172.

Bonafoni, S., Biondi, R., 2016. The usefulness of the global navigation satellite systems (GNSS) in the analysis of precipitation events. Atmos. Res. 167, 15-23.

Burgos Fonseca, Y., Alexander, P., de la Torre, A., Hierro, R., LLamedo, P., Calori, A. 2018. Comparison between GNSS ground-based and GPS radio occultation precipitable water observations over ocean-dominated regions. Atmos. Res. 209, 115-122. https://doi.org/10.1016/j.atmosres.2018.03.017.

Calori, A., Santos, J., Blanco, M., Pessano, H., 2016. Ground-based GNSS network and integrated water vapor mapping during the development of severe storms at the Cuyo region (Argentina). Atmos. Res. 176-177, 267-275.

Chou, M.-D., Weng, C.-H., Lin, P.-H., 2009. Analysis of FORMOSAT-3/COSMIC humidity retrievals and comparisons with AIRS retrievals and NCEP/NCAR reanalysis. J. Geophys. Res. 114, D00G03.

do Nascimento, M.G., Herdies, D.L., Oliveira de Souza, D., 2016. The South American water balance: The influence of low-level jets. J. Climate 29, 1429-1449.

Hierro, R., Llamedo, P., de la Torre, A., Alexander, P., Rolla, A., 2012. Climatological patterns over South America derived from COSMIC radio occultation data. J. Geophys. Res. 117, D03116. https://doi.org/10.1029/2011JD016413.

Hierro, R., Llamedo, P., de la Torre, A., Alexander, P., 2013. Oscillation modes of humidity over the Amazon basin derived from GPS RO profiles. J. Geophys. Res. 118, 13121-13127. https://doi.org/10.1002/2013JD020758.

Ho, S.-P., Zhou, X., Kuo, Y.-H., Hunt, D., Wang, J.-H., 2010. Global evaluation of radiosonde water vapor systematic biases using GPS radio occultation from COSMIC and ECMWF analysis. Remote Sens. 2, 1320-1330. https://doi.org/10.3390/RS2051320.

Huang, C.Y., Teng, W.H., Ho, S.P., Kuo, Y.H., 2013. Global variation of cosmic precipitable water over land: Comparisons with ground-based gps measurements and ncep reanalyses. Geophys. Res. Lett. 40, 5327-5331. https://doi.org/10.1002/grl. 50885.

Kalnay, E., Kanamitsu, M., Kistler, R., Collins, W., Deaven, D., Gandin, L., Iredell, M., Saha, S., White, G., Woollen, J., Zhu, Y., Chelliah, M., Ebisuzaki, W., Higgins, W., Janowiak, J., Mo, K.C., Ropelewski, C., Wang, J., Leetmaa, A., Reynolds, R., Jenne, R., Joseph, D., 1996. The NCEP/NCAR 40-Year Reanalysis Project. Bull. Amer. Meteor. Soc. 77, 437-472.

Kishore, M., Ratnam, V., Namboothiri, S.P., Velicogna, Isabella, Ghouse Basha, J.H., Jiang, K. Igarashi, Rao, S.V.B., Sivakumar, V., 2011. Global (50S-50N) distribution of water vapor observed by COSMIC GPS RO: Comparison with GPS radiosonde, NCEP, ERA-Interim, and JRA-25 reanalysis data sets. J. Atmos. Sol. Terr. Phys. 73, 1849-1860. https://doi.org/10.1016/j.jastp.2011.04.017.

Kuleshov, Y., Choy, S., Fu, E.F., Chane-Ming, F., Liou, Y.-A., Pavelyev, A.G., 2016. Analysis of meteorological variables in the Australasian region using ground- and space-based GPS techniques. Atmos. Res. 176-177, 276-289. https://doi.org/10. 1016/j.atmosres.2016.02.021.

Llamedo, P., Hierro, R., de la Torre, A., Alexander, P., 2016. ENSO-related moisture and temperature anomalies over South America derived from GPS radio occultation 
profiles. Int. J. Climatol. 37, 268-275. https://doi.org/10.1002/joc.4702.

Nobre, C., Silva Dias, M., Culf, M., Alistair, D., Polcher, J., Gash, J., Marengo, J., Avissar, R., 2004. The Amazonian climate. In: Kabat, P. (Ed.), Vegetation, Water, Humans and the Climate. Springer, London, pp. 79-88.

Oliveira, R., Maggioni, V., Vila, D., Morales, C., 2016. Characteristics and diurnal cycle of GPM rainfall estimates over the central Amazon region. Remote Sens. 8, 544. https:// doi.org/10.3390/rs8070544.

Pettitt, A.N., 1979. A non-parametric approach to the change-point detection. J. R. Statist. Soc. C 28, 126-135. https://doi.org/10.2307/2346729.

Seidel, D.J., 2002. Water vapor: Distribution and trends. In: Encyclopedia of Global
Environmental Change. Wiley, New York, pp. 750-752.

Teng, W.-H., Huang, C.-Y., Ho, S.-P., Kuo, Y.-H., Zhou, X.-J., 2013. Characteristics of global precipitable water in ENSO events revealed by COSMIC measurements. J. Geophys. Res. Atmos. 118, 8411-8425. https://doi.org/10.1002/jgrd.50371.

Vergados, P., Mannucci, A.J., Ao, C.O., Verkhoglyadova, O., Iijima, B., 2018.

Comparisons of the tropospheric specific humidity from GPS radio occultations with ERA-Interim, NASA MERRA, and AIRS data. Atmos. Meas. Tech. 11, 1193-1206.

Wang, C., 2005. ENSO, Atlantic climate variability, and the Walker and Hadley circulations. In: Diaz, H.F., Bradley, R.S. (Eds.), The Hadley Circulation: Present, Past and Future. Kluwer, New York, pp. 173-202. 